\title{
Interaction between turbidity currents and a contour current - A rare example from the Ordovician of Shaanxi province, China
}

\author{
Hua $\mathrm{Li}^{1,2}$, A.J. (Tom) van Loon 3 , Youbin $\mathrm{He}^{1,2^{*}}$ \\ ${ }^{1}$ School of Geosciences, Yangtze University, Wuhan, 430100, China; e-mail: LH840607@126.com, 501026@yangtzeu. \\ edu.cn (H. Li), heyoubin@yangtzeu.edu.cn (Y. He) \\ ${ }^{2}$ Research Center of Sedimentary Basin, Yangtze University, Wuhan, 430100, China \\ ${ }^{3}$ College of Earth Science and Engineering, Shandong University of Science and Technology, Qingdao 266590, \\ Shandong, China; e-mail: Geocom.VanLoon@gmail.com \\ *corresponding author.
}

\begin{abstract}
The silty top parts of graded turbidites of the Late Ordovician Pingliang Formation, which accumulated along the southern margin of the Ordos Basin (central China), have been reworked by contour currents. The reworking of the turbidites can be proven on the basis of paleocurrent directions in individual layers: the ripple-cross-bedded sandy divisions of some turbidites show transport directions consistently into the downslope direction (consistent with the direction of other gravity flows), but in the upper, silty fine-grained division they show another direction, viz. alongslope (consistent with the direction that a contour current must have taken at the same time). Both directions are roughly perpendicular to each other. Moreover, the sediment of the reworked turbidites is better sorted and has better rounded grains than the non-reworked turbidites.

Although such type of reworking is well known from modern deep-sea environments, this has rarely been found before in ancient deep-sea deposits. The reworking could take place because the upper divisions of the turbidites involved are silty and consequently relatively easily erodible, while the contour current had locally a relatively high velocity - and consequently a relatively large erosional capability - because of confinement within a relatively narrow trough.
\end{abstract}

Key words: contourites, turbidites, reworking, Ordos Basin, Pingliang Formation

\section{Introduction}

Contour currents are continuous bottom currents, whereas gravity flows (such as turbidity currents) are periodical flows of varying thickness. When contour currents and gravity flows reach the same place at the same time, interaction takes place. Because such interaction takes most commonly place in deep-marine environments, analysis is difficult, and the process is known almost exclusively from studies of modern deep-sea environments; evidence of such interaction in the geological record is extremely scarce and restricted to Cenozoic sedi- ments (Stanley, 1993; Kähler \& Stow, 1998; Rasmussen et al., 2003). The present contribution is the first one dealing with sedimentological data indicating such interaction in older sediments.

\subsection{Interacting contour currents and gravity flows in modern environments}

Deep-sea environments are not well accessible for true field work. Studies about contour currents and deep-sea gravity flows were therefore performed mainly using multibeam seismics and drilling data. 
Such studies have been carried out particularly in the Gulf of Mexico (Shanmugam et al., 1993a,b), the Argentine slope (Hernández-Molina et al., 2009), the Algarve margin (Marchès et al., 2010; Salles et al., 2010), the South China Sea (Gong et al., 2013, 2016; Li et al., 2013, 2014), the Southern Brazil Basin (Massé et al., 1998, Gonthier et al., 2003), East Antarctica (Kuvaas et al., 2005), the Weddell Sea (Michels et al., 2001), and the Gulf of Cadiz (Mulder et al., 2006; Rooij et al., 2010).

Interaction between contour currents and gravity flows can take place in three forms, viz. (1) reworking of gravity-flow deposits by contour currents, (2) alternation of contourites and gravity flows, and (3) simultaneous activity of a contour current and a gravity flow at a specific place (Mulder et al., 2008). These three types of interaction are, at least in principle, reflected in the resulting sediments, which should show not only a combination of characteristics of the two types of deposits (Hernández-Molina et al., 2015; Li et al., 2013; Gong et al., 2018), but also a combination of their specific types of sedimentary structures. Most interesting in this context is that contour currents flow parallel to the isohypses of a basin slope, whereas gravity flows run perpendicular to them (this is also the reason why such flows must, by definition, interact). The current ripples in the deposits of these two types of flows (contourites and gravity-flow deposits, more specifically turbidites because most other types of gravity flows do not result in current ripples) should consequently show transport directions that are more or less perpendicular to each other. This feature is not really known from ancient deposits. This is understandable, however, because the locations where contour currents and gravity flows meet each other are very small in comparison to the total extent of their deposits; moreover, contour current are a long-lived phenomenon, so that the traces of such interaction may become eroded or erased in the course of time.

Traces of reworking may be left also in the form of divergent compositions of the sediments, and in divergent grain characteristics (grain-size distribution, rounding, etc.). This is because contourites show, as a rule, better sorting, better rounding and less matrix than gravity-flow deposits; moreover they tend to show more bioturbation/burrowing in their top parts (Shanmugam et al., 1993a,b; Stow and Faugères, 2008; Gong et al., 2015).

\subsection{Lack of studies in ancient sediments}

Although interaction between contour currents and turbidites must have occurred in the geological past, hardly any data are as yet available from the geological record regarding this feature. Although this is understandable, as detailed in the previous section, it is remarkable since both ancient contourites and ancient turbidites have been described and analyzed in detail. Ancient deposits that represent interaction between contour currents and gravity flows consequently deserve more attention. Important aspects that might need more study concern several questions that are not yet well understood, particularly (1) what are the sedimentary processes involved in the interaction between gravity flows and a contour current, and (2) how these interactions can be identified in the sedimentary record.

The present contribution is aimed at increasing the insight into the above-mentioned aspects. This is

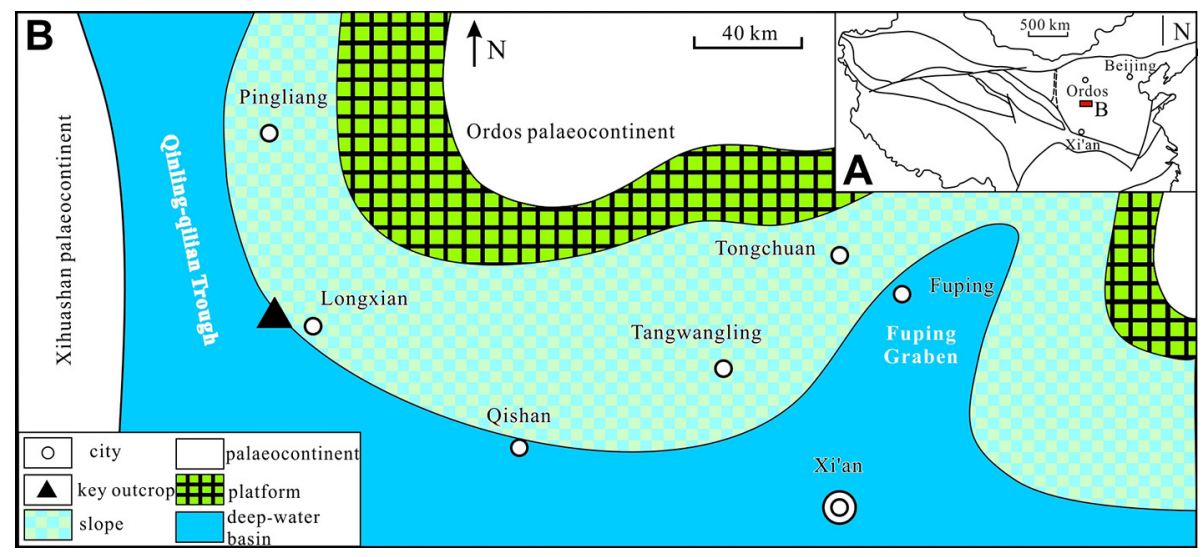

Fig. 1. Location and geological setting of the study area (modified from Wu \& Feng, 1994). A - Position of the study area within the Ordos Basin (red rectangle) in its structural setting. The black lines indicate the boundaries between the major tectonic units of China; B - Palaeogeography map of the study area during the Ordovician with location of the study sites. The basin consisted of, from north to south, a platform, a slope, and a deep-marine basin with the Qinling-Qilian Trough in the west 

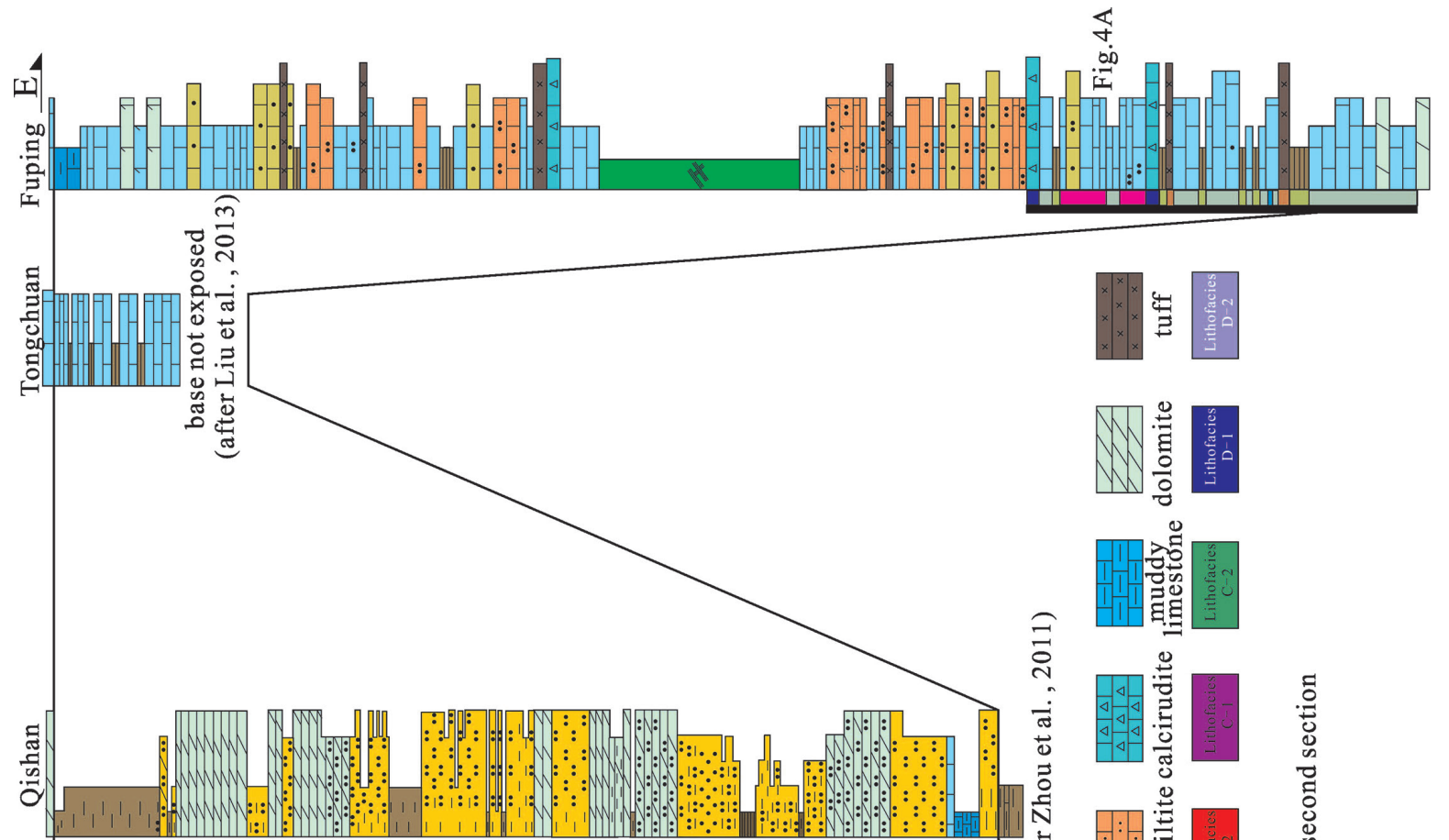

W.

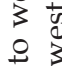

范

ฮี

:
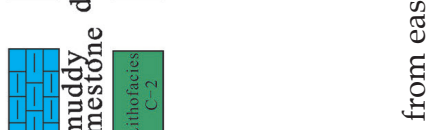

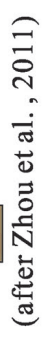

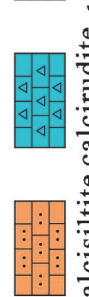

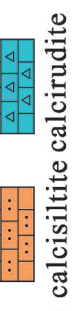

灵

돌

올 올

हृํㅇ

है

동

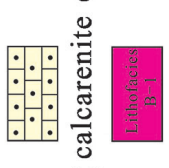
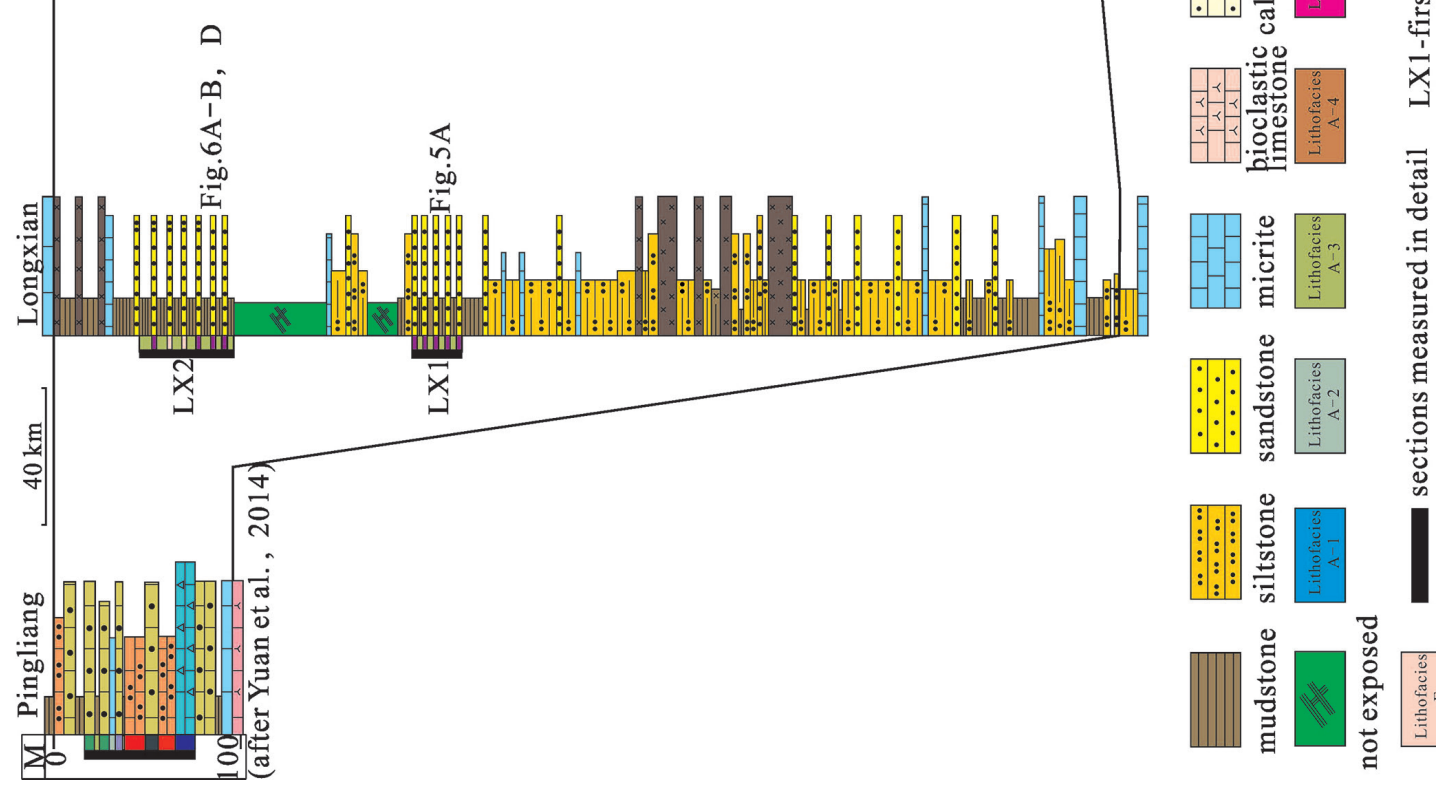

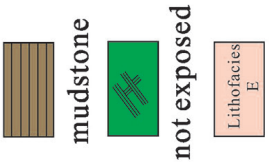

bo

ป

के

s.

䒕 웜

을

氖吉

ธี.

है 


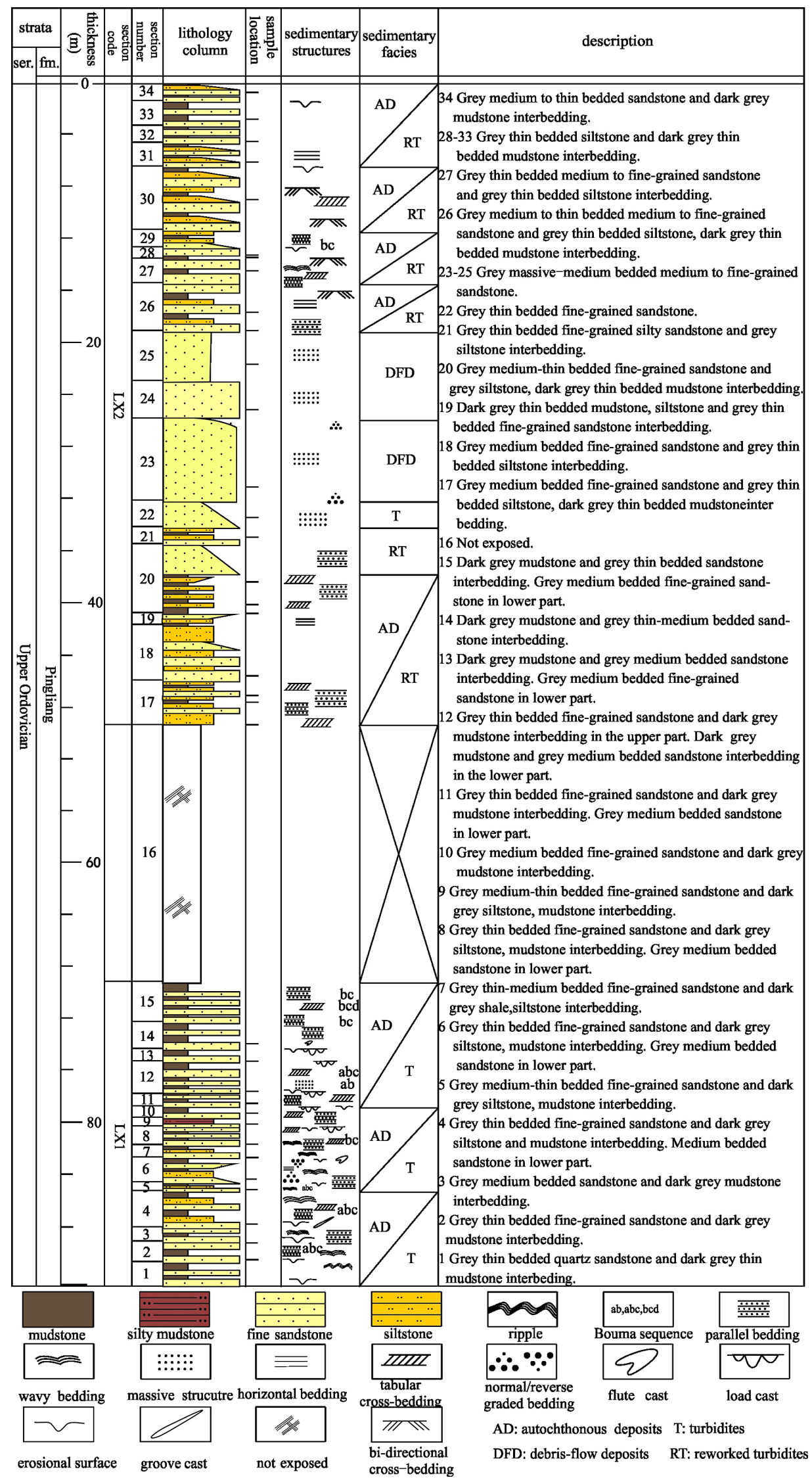

Fig. 3. Lithology and facies of the Pingliang Fm. at Longxian 
done by investigation of the Late Ordovician Pingliang Formation in the Ordos Basin (Fig. 1), where both turbidites (and other mass-flow deposits) and contourites are well developed (Li et al., 2016, 2017). Interaction between gravity flows and contour currents has nevertheless not been studied earlier for this formation.

\section{Geological setting}

The Ordos Basin (Fig. 1) occupies an area of approx. $0.25 \times 10^{6} \mathrm{~km}^{2}$ (Guo et al., 2014; Song et al., 2013; Wang et al., 2015) or $0.32 \times 10^{6} \mathrm{~km}^{2}$ if the surrounding Cenozoic grabens are included (Yang et al., 2017). The study site near Longxian is situated at the transition between a deep-marine slope and adjoining basin which partly developed in the Qinling-Qilian Trough, which is located between the Xihuashan and Ordos paleocontinents (Wu \& Feng, 1994). The Longxian site is situated in the funnel-shaped entrance of the Qinling-Qilian Trough (Fig. 1).

The Ordovician of the southern marginal part of the Ordos Basin is subdivided, from bottom to top, into the Yeli, Liangjiashan, Sandaogou/Fengfeng, Pingliang and Beiguoshan Formations (Yang et al., 2019). The sediments under study here belong to the Pingliang Formation, which is Late Ordovician in age. The eastern and western parts of the formation represent carbonate zones, but the middle part consists of clastic rocks (Fig. 2).

\section{Methods}

The analysis of the sediments under study is based mainly on (1) field data from outcrops, (2) measurements of paleocurrent directions, and (3) petrological analysis of thin sections.

The sedimentary succession that contains the turbidites that were reworked by a contour current was studied in a section near Longxian (Fig. 3). The paleocurrent directions in this section were measured from small asymmetrical current ripples, cross-bedding, and flute casts. By combining these measurements with an analysis of the transporting agent (contour current or gravity flow), the pathways of both types of flows could be reconstructed.

The various facies will be described in detail in another study; consequently, we provide in our description and analysis of the various facies (Section 4) only the overall characteristics and their interpretation.

\section{The Longxian section}

We distinguish eleven lithofacies in the Pingliang Formation (Table 1). The eleven facies are grouped into five lithofacies associations (A-E). These facies associations are shortly dealt with in Sections 4.1 through 4.5. The section under study, situated near Longxian, has a relatively simple lithology; it is built of sandstones, mudstones and a small amount of siltstones. The sediments belong to lithofacies associations A, C, D and E. Remarkably enough (as will be detailed below) no sediments are present that clearly represent association $B$.

Part of the section at Longxian is not exposed. The lower exposed part (LX1 in Fig. 2) is $22.4 \mathrm{~m}$ thick and consists of alternating mudstones and sandstones. Ripple-cross-bedding and flute casts are common. The various sediments represent autochthonous deep-sea debris-flow deposits and turbidites. The upper exposed part of the section (LX2 in Fig. 2) consists of sandstones, mudstones and a few siltstones with cross-bedding, wavy lamination, and bioturbation structures. This is the part of the section in which, in addition to autochthonous sediments and 'normal' turbidites, graded turbidites occur that show cross-bedding in the upper silty Bouma division indicating transport in a direction roughly perpendicular to the transport direction indicated by the ripple-cross-bedding in the lower sandy Bouma division (see Section 4.5).

\subsection{Autochthonous sediments}

\subsubsection{Description}

Lithofacies association A is represented by horizontally bedded dark grey mudstones that are a few up to $40 \mathrm{~cm}$ thick. They contain abundant graptolites, as already described by He et al. (2007). Trace fossils, such as Helminthoida, Paleodictyon, and Squamodictyon, are very common on the upper surfaces of the mudstones. Bioclasts occur mainly on top of the mudstone layers, particularly where they are overlain by sandstones. Some pyrite crystals occur in the mudstones.

\subsubsection{Interpretation}

The mudstones are characteristic of settling from suspension in the quiet water of a deep-sea environment. The graptolites and the trace fossils, Helminthoida, Paleodictyon, and Squamodictyon, also indicate a deep-sea environment. The pyrite crystals indicate anoxia or dysoxia conditions. 


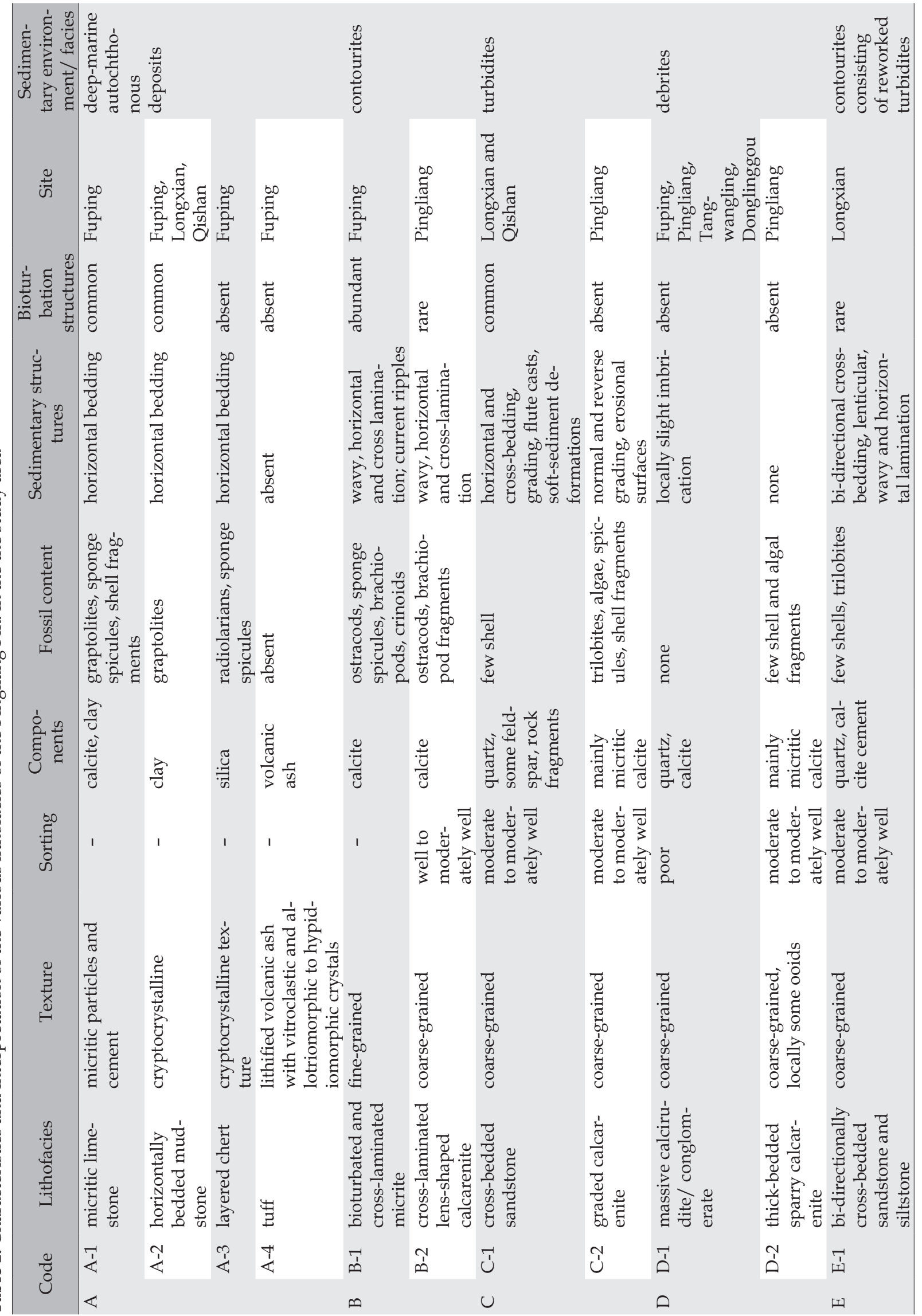




\subsection{Contourites}

\subsubsection{Description}

Lithofacies association B is well developed at the Fuping and Pingliang sites (Fig. 1).

At the Fuping site, the sediments consist of micrites of 1-15 cm thick with wavy and cross-lamination. The layers, which have undulating boundaries, show thin-thick-thin cycles due to fine-coarse-fine alternations (Fig. 4A-C). The ripples are asymmetric with a length of $1-5 \mathrm{~cm}$ and a height of $0.2-0.5 \mathrm{~cm}$. The ripples and cross-lamination indicate a current direction from NW to WNW (Fig. 4D). The sediments contain ostracods, sponge spicules, brachiopods, and crinoids. Trace fossils are common. Some burrows are perpendicular to bedding.

At the Pingliang site, the sediments consist of calcarenites. The features here are similar to those at the Fuping site, including the cross-lamination and current direction.

\subsubsection{Interpretation}

The lithofacies is interpreted as built by contourites on the basis of the following considerations: (1) the environment is deep marine; (2) the currents ran from NW to WNW, which is parallel to the isohypses of the slope in both the Fuping and the Pingliang regions, which is a diagnostic feature of contour currents (Hernández-Molina and Stow, 2008); (3) contourites tend to have undulating surfaces (Stow et al., 2002), as shown by the sediments of this lithofacies; (4) the fine-coarse-fine cycles are one of the most characteristic features of contourites (Duan et al., 1993; Stow et al., 2002); (5) bioturbation tends to be well developed in contourites (Duan et al., 1993; Stow et al., 1998; Wetzel and Stow, 2008).

\subsection{Turbidites}

\subsubsection{Description}

Lithofacies association $\mathrm{C}$ is represented at Longxian by layers that are jointly 40.89 m thick, thus constituting more than half (57.5\%) of the section (Fig. 3). The individual cross-bedded sandstones are 11-40 $\mathrm{cm}$ thick. The turbidites (Fig. 5A-C) show grading, horizontal lamination, small-scale cross-bedding and parallel lamination (Fig. 5A-C), in de vertical order of Bouma divisions (Bouma, 1962); these dif-
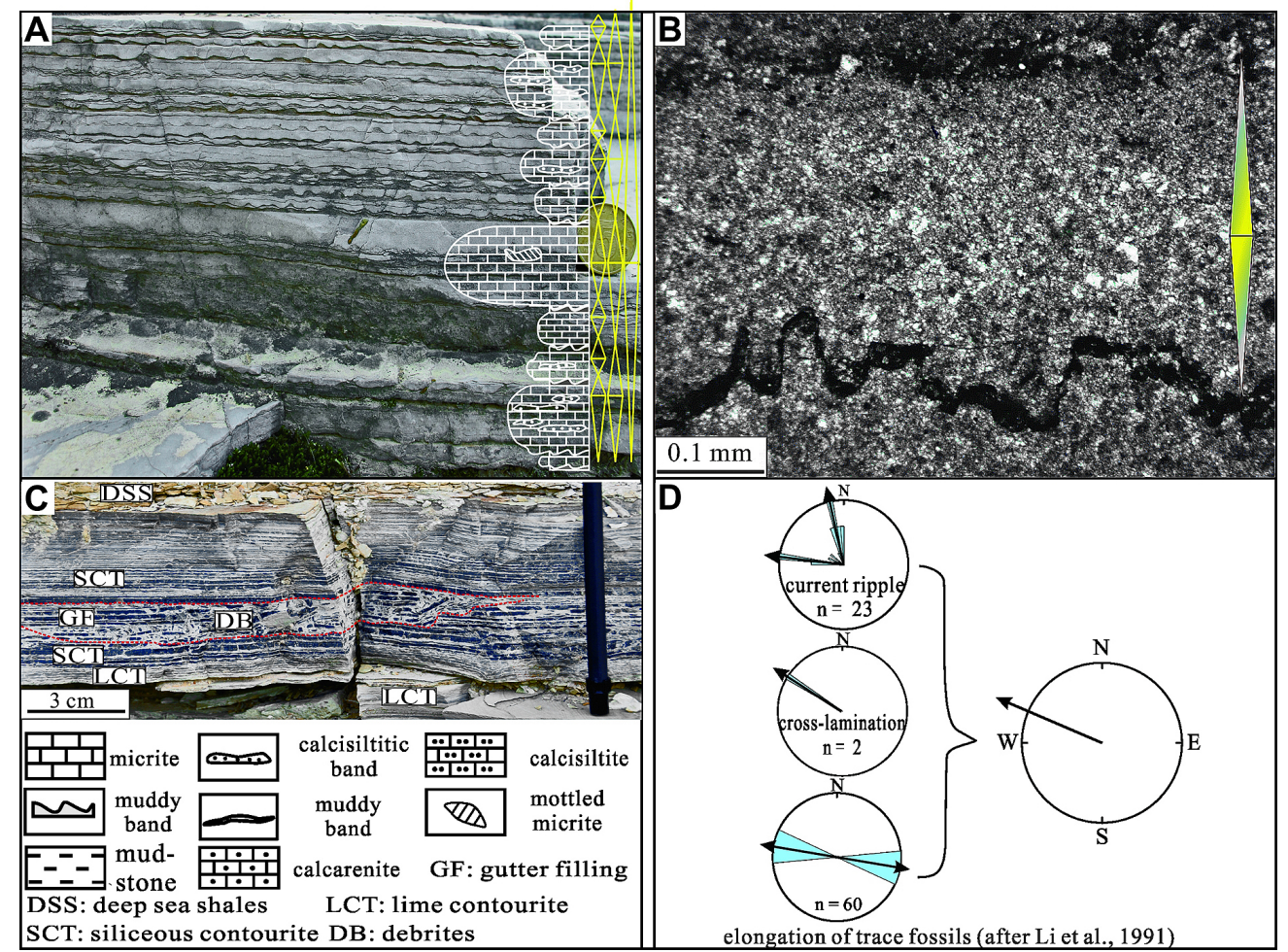

Fig. 4. Characteristics of lithofacies B. A - Micrite contourites at the Fuping site. The layers show thin-thick-thin cycles, corresponding with fine-coarse-fine cycles; B - Microphoto of a thin section of a contourite at the Fuping site, showing the characteristic grain-size couplets; C - Contourites in the Fuping area with an incised channel filled by a debrite. The contourites are covered by deep-sea autochthonous shales, showing fine-coarse-thin cycles. From Yang et al. (2019), with permission; D - Palaeocurrent directions, as measured for contourites at the Fuping site, were parallel to the slope 

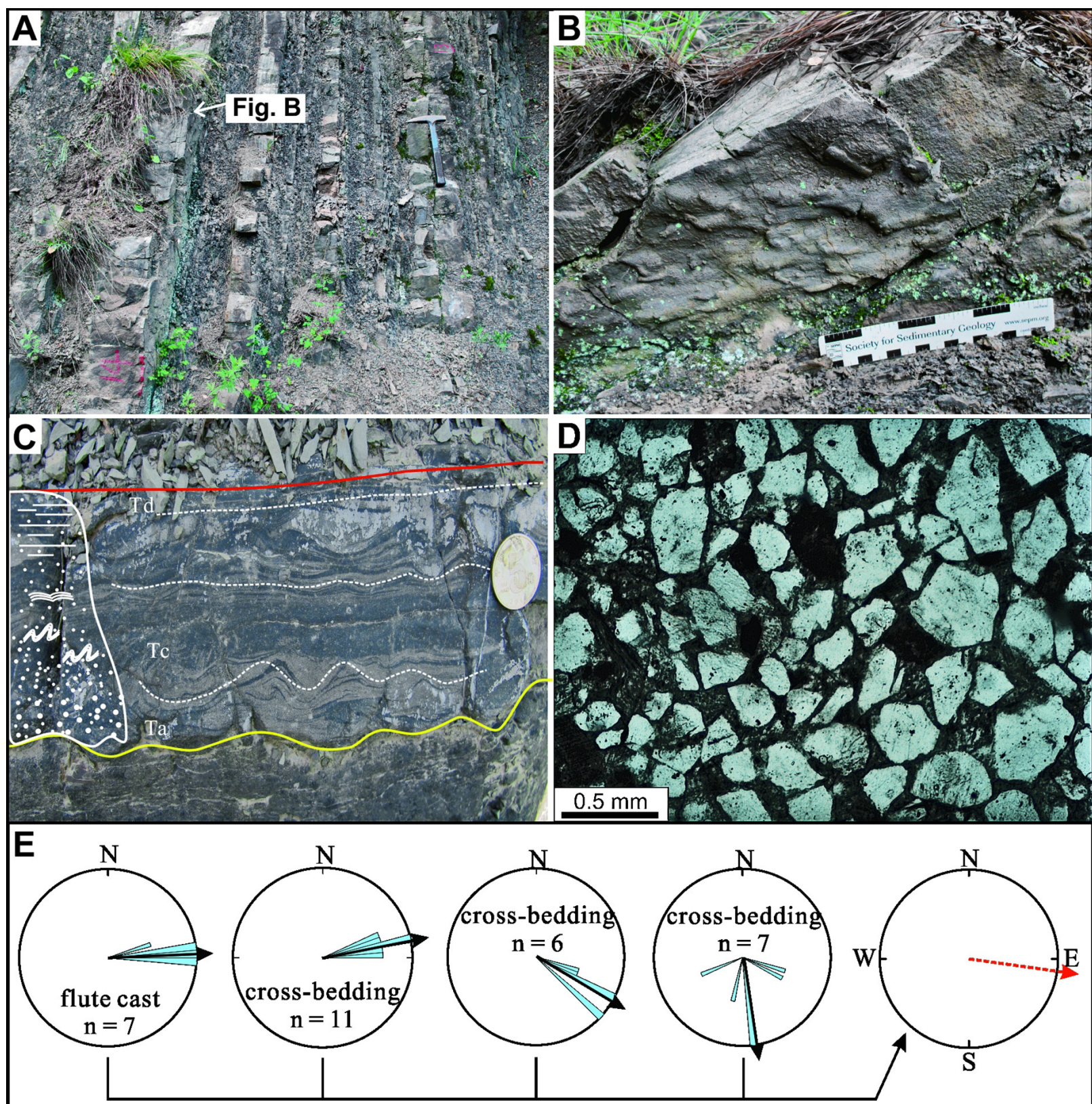

Fig. 5. Characteristics of lithofacies $C$ at the Longxian site. A - Overview of part of the outcrop with a succession consisting of lithofacies C; B - Flute casts at the bottom of a sandstone turbidite. For location, see Figure 5A; C - Succession of a turbidite with a well-developed but incomplete Bouma sequence; D - Microphoto of a turbidite, showing angular to subangular grains; E - Palaeocurrent directions, as measured in the lower detailed section (LX1; see Fig. 2) from current ripples and sole marks, showing transport from WNW to ESE

ferent Bouma divisions are, however, not always all present. The grains are angular to subangular (Fig. 5D). Flute and groove casts are common at the lower boundaries (Fig. 5B). Trace fossils are common on the upper surfaces of the sandstones (Fang \& Mao, 2007; Li et al., 1991); they are represented by Helminthoida, Paleodictyon, and Squamodictyon.

Paleocurrent directions have been measured from 7 flute casts and 24 cross-beddings. The flute casts indicate a paleocurrent direction from west to east, whereas the cross-beddings show a direction from WNW to ESE (Fig. 5E). The turbidity currents ran down the basin slope that can be deduced from the lateral facies changes.

\subsubsection{Interpretation}

The vertical order of (sometimes incomplete) Bouma divisions is diagnostic for turbidites (cf. Bouma, 1962; Mulder et al., 2001; Mutti et al., 2009). The presence of flute and groove casts is another indica- 
tion. The downslope transport is consistent with the above interpretation. The combination of all these data allows to deduce that this lithofacies represents deposition by turbidity currents.

\subsection{Debris-flow deposits}

\subsubsection{Description}

Lithofacies association D is represented by sandy sediments which consist of medium to fine quartz grains. The thickness of individual layers is 0.6-2.0 $\mathrm{m}$. Sedimentary structures are absent, apart from some rare cases of graded bedding.

\subsubsection{Interpretation}

The massive, commonly thick layers without sedimentary structures show that they were not deposited by traction currents, but rather represent event deposits (cf. Middleton \& Hampton, 1973; Mutti et al., 2009). The lack of sedimentary structures, the poor sorting and the absence of Bouma intervals indicates that they cannot be turbidites. This lithofacies association must therefore represent debris-flow deposits.

\subsection{Reworked sediments}

The layers belonging to association E, which is present in the Longxian section but not elsewhere in the Pingliang Formation, are jointly $8.77 \mathrm{~m}$ thick, thus constituting about $6 \%$ of the entire Longxian section (Figs. 3 and 6). The sediments are interpreted to represent graded turbidites of which the silty top parts have been reworked by a contour current. These sediments are the main subject of the present contribution. The characteristics and their analysis are detailed in Section 5 and discussed in Section 6.

\section{The reworked turbidites}

Some of the turbidites show in their upper, finegrained part current ripples that indicate a transport direction at a high angle to the transport direction indicated by the current ripples in the lower part of these turbidites. This remarkable feature is the main topic of the present contribution.

\subsection{Description}

The sediments under study here consist of grey-colored fine- to medium-grained sandstones that show normal grading; occasionally the top part thus consists of siltstone rather than sandstone (Fig. $6 \mathrm{~A}-\mathrm{B})$. The layers are $10-40 \mathrm{~cm}$ thick, with straight or curved lower and upper boundaries (Fig. 6A-B). The sediments are built of subangular to subrounded quartz grains with a predominantly calcareous, sometimes siliceous or muddy, cement (Fig. 6C). Erosional surfaces tend to occur both within and on top of the sand/siltstone. Trace fossils occur at the upper surface of the layers (Fig. 6D). Internal structures (cross-bedding, and wavy and parallel lamination) are common. Cross-bedding is most common in the fine sandstone and siltstone, and has been measured $(n=105)$ for paleocurrent analysis. It appears that the cross-bedding indicates two mutually perpendicular transport directions, even in one single layer (Fig. 6E-F). A total of 28 cross-beddings were measured in this single layer; they indicate transport directions from $E$ to $W$, and from WSW to ENE or NW to SE (Fig. 6F). This clearly differs from other lithofacies, in which in total 105 paleocurrents were measured, all showing that the transport directions were consistently from $\mathrm{E}$ to $\mathrm{W}$ or from NW to SE. On the basis of the well-known palaeotopography of the basin, it can be deduced that the transport from east to west was parallel to the contour lines; the other transport direction was downslope.

\subsection{Interpretation}

The sediments under study, which occur in close association with autochthonous mudstones that point at a relatively quiet deep-sea environment that was, however, occasionally interrupted by events that resulted in turbidites and debris-flow deposits, differ from all other sediments of the Pingliang Formation because they show (1) paleocurrents into two distinctly different directions (to the $\mathrm{W}$ and to the SE); (2) better rounded grains and better sorted sediments than in the turbidites and debris-flow deposits, but less rounded grains and less well sorted sediments than in the contourites that are present at sites immediately to the east and the west; (3) a matrix that contains not only clay, but also calcite (that is also present as a cement); (4) Bouma sequences of which the top part has commonly been reworked; and (5) erosional surfaces, both within the layer and on top of the finer sandstone and siltstone parts.

Based on the data presented above, and taking the following considerations into account, it is deduced that these sediments represent turbidites that have been reworked by contour currents; such deposits have also been called "reworked turbidites" (Gong 
et al., 2016; Shanmugam et al., 1993a,b; Stow et al., 1998, Stow \& Faugères, 2008). The following five aspects are the most important for this interpretation.

1. The amount of silt- and other fine-grained particles in the turbidites under study is larger at
Longxian than elsewhere in the Pingliang Formation. The contour current that must have been present at this site, in contrast, was steadily running, and must have been strong enough to winnow and rework the fine-grained material of the
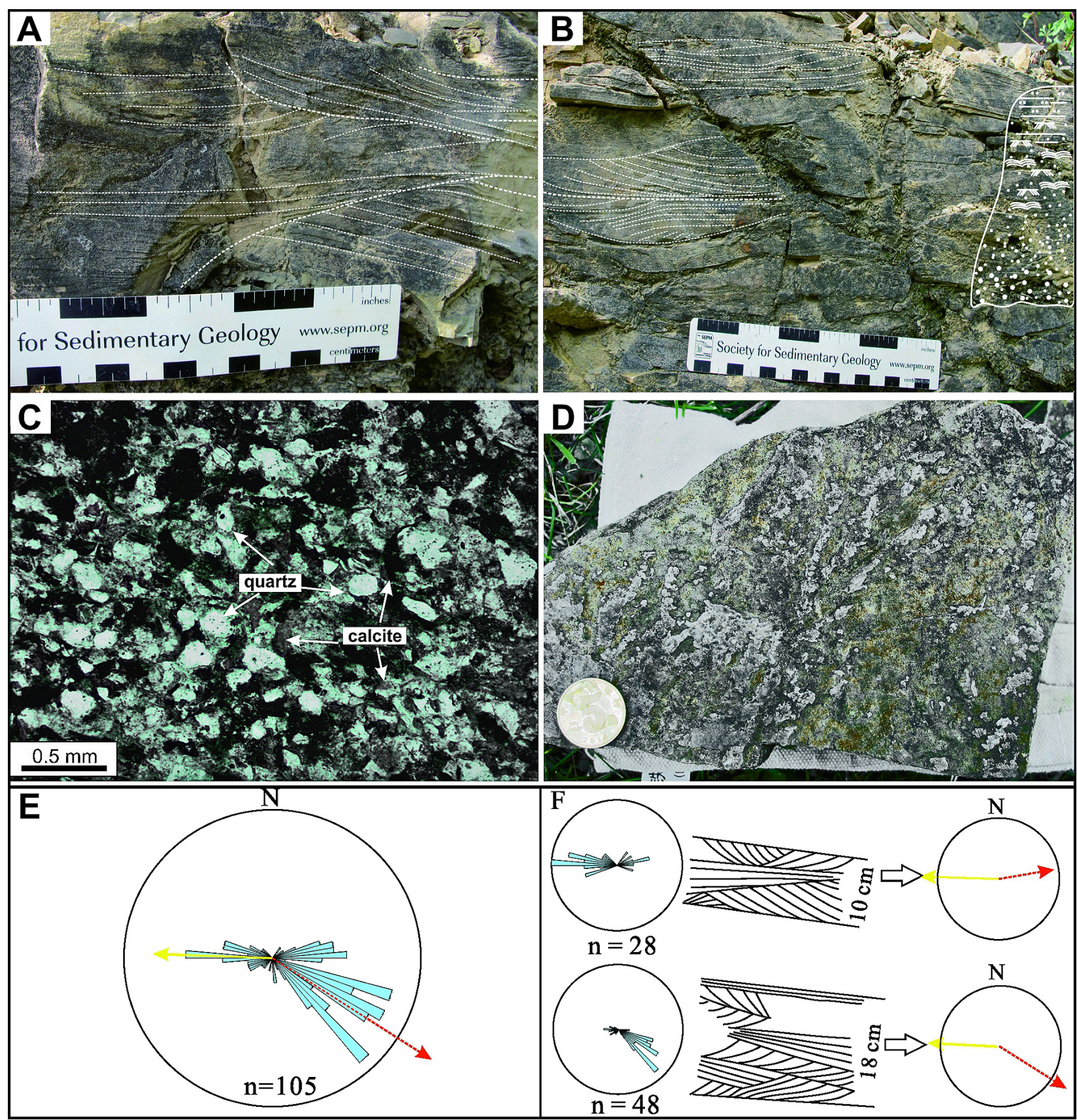

Fig. 6. Characteristics of lithofacies E. A-B - Sandy turbidite with a reworked upper fine-grained top part. Note the cross-bedding in different directions that are described and analyzed in the text; C - Microphoto of a partly reworked turbidite, showing quartz grains cemented by calcite; D - Trace fossils on the upper surface of a partly reworked turbidite; E - Palaeocurrent measurements in all reworked turbidites; F - Palaeocurrent measurements in a single reworked turbidite (section LX2; see Fig. 2), showing two different current directions: one (in the lower part of the layer) to the southeast (= downslope), left by a turbidity current, and one (in the upper part of the layer) to the west (= parallel to the slope), left by a contour current. Figs. E \& F - Yellow vectors indicate contour current direction, red vectors indicate turbidity current direction 
top parts of the turbidites. This represented an uncommon situation, because the velocity, and consequently also the energy, of turbidites and other gravity flows that run down a slope tends to be higher than that of a contour current. It is therefore more likely that gravity flows or turbidity currents rework material that was earlier deposited by a contour current. On this distal part of the slope, however, the turbidity currents had lost most of their energy, and consequently of their erosional capability, and deposited only fine-grained material, possibly just before they stopped completely. On the other hand, the contour current followed at this site a relatively narrow pathway and consequently had a relatively high energy, so that the erosional capability of the contour current was occasionally high enough to rework some of the fine-grained top part of the turbidites.

2. Two distinctly different paleocurrent directions are present in the same turbidite. One is directed southeastwards, which represents the downslope direction of the turbidity currents. The other one is directed westwards, thus at a high angle (even almost perpendicular) to the first one, parallel to the contour lines. There are no channels, canyons or other depressions at Longxian parallel to the slope, so that only a contour current, running from east to west, can explain this satisfactorily (cf. Stow et al., 1998; Stow \& Faugères, 2008).

3. The erosional surfaces occur not only inside the individual layers but are even more common in the top part of the graded layers with an incomplete Bouma sequence, which indicates strong reworking of the turbidites (Stanley, 1993; Stow et al., 1998).

4. Trace fossils are well developed on the upper surfaces of the layers, which suggests a steady environment hardly influenced by events, which is typical for environments in which contourites can accumulate (Duan et al., 1993; Stow et al., 1998; Wetzel \& Stow, 2008).

\section{Discussion}

\subsection{The inferred contour current}

A contour current must have been present at the Longxian site despite the absence of well-developed contourites. This cannot be deduced directly from the geological succession, as lithofacies E, which is present only at the Longxian site, is interpreted as consisting of turbidites that were reworked by a contour current (see section 5.2). The features of this lithofacies are, however, similar to those described by Stow et al. (1998) and Stow \& Faugères (2008) for contour currents that reworked turbidites. As will be detailed further on, this concerns the relatively good sorting of the turbidites at this site, the cross-bedding indicating two current directions, the common bioturbation, etc.

The absence of recognizable contourites in the section at Longxian can be well explained by the following two arguments: (1) some parts of the section are not exposed and these parts may contain the typical contourites (admittedly, this is not a strong argument); (2) a much stronger argument is that, although a contour current must have been present, most of the turbidity currents that passed this location must have had a higher erosional capability than the contour current. The turbidity currents thus were not only capable to destroy the contourites that they crossed, but also to affect the sedimentary process of the contourites, which explains that the typical contourite features (undulating boundaries, fine-coarse-fine cycles, slope-parallel paleocurrent structures) were erased at Longxian by the turbidity currents, although these must represent events that occurred during only a fraction of the time involved in the accumulation of the sedimentary succession.

This interpretation is supported by the following aspects.

1. A contour current, which moves along a slope, results from thermohaline circulation, and its dimensions tend to be huge (Rebesco et al., 2008, 2014).

2. Contour currents running from east to west were present at both the Fuping site (east of Longxian) and the Pingliang site (west of Longxian) (Gao et al., 1995, 1998; Li et al., 1991, 2016; Qu et al., 2010), as can be deduced from the well-developed contourites at those sites. The contourites there were preserved because of the much rarer occurrence (or even absence) of gravity flows (see Fig. 2) that could destroy them. Because the contour currents present at Fuping could reach Pingliang only through the basin where Longxian is situated in between those sites, a contour current must have passed the Longxian region.

3. The Longxian site is situated in the funnel-shaped entrance of the Qinling-Qilian Trough, which must have resulted in an increase of the velocity of the contour current to such a level that it became capable of reworking fine-grained, water-saturated turbidite material. 


\subsection{Possible interaction between turbidity currents and the contour current}

The sediments under study here represent the sedimentologically most interesting deposits of the Pingliang Formation, because they show interaction between gravity-induced flows and contour currents. Their occurrence, though very rarely mentioned in the literature (Kähler \& Stow, 1998; Stanley, 1993), is not surprising as contour currents are fairly stable and long-lived features, so that it is only logical that they have occasionally been hit by mass flows. Commonly the erosive power of turbidity currents must have been sufficient to erode contourites. As we will detail below, there is evidence that this happened, indeed, but the evidence is circumstantial rather than direct. Moreover, the permanent character of the contour currents implies that such currents must have reworked the turbidites that earlier had reworked the deposits formed earlier by the same contour current.

Because (continuous) contour currents follow the contour lines, whereas (periodic) gravity flows run roughly perpendicular to the contour lines, the two types of currents must cross each other occasionally, and thus must interact. What happens on these occasions strongly depends on the relative energy and mass of both types of current.

In the study area both the contour and turbidity currents mostly had a relatively high energy. The velocity of the contour currents was presumably comparable with those in the modern Gulf of Mexico (due to a confined environment) and was particularly high when they entered a regional trough. The velocity of contour currents is commonly only 5-20 $\mathrm{cm} \mathrm{s}^{-1}$, which implies a relatively low energy (Heezen et al., 1966; Stow \& Lovell, 1979); occasionally, however, the velocity can reach 50-100 $\mathrm{cm} \mathrm{s}^{-1}$, particularly when the contour current flows in a confined environment (Stow et al., 2009; Viana, 2008). The high velocity of the contour current then can result in sand waves, sheets, and dunes, like in the Campos Basin, Gulf of Mexico (Kenyon et al., 2002; Stow et al., 2009; Viana et al., 2002).

We noticed the following for the study area. The high-velocity contour current was sufficiently strong to whirl up and rework the fine-grained topmost sediments deposited by turbidity currents, but not the lower, coarser (sandy) parts. Thus, two current directions (alongslope and downslope) are present in the same layers: in the lower part of the affected turbidite, the ripples indicating downslope transport by the turbidity current are preserved, whereas the contour current resulted in current ripples in the upper part that indicate an alongslope

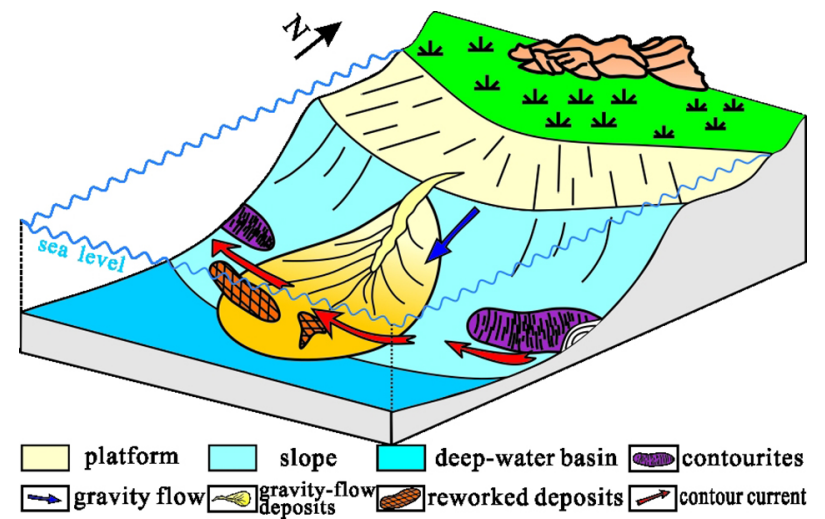

Fig. 7. Schematic model (not to scale) of the setting in which the contour current could erode the finegrained top parts of previously deposited turbidites.

transport. The contour currents could winnow and rework the fine-grained turbidites thanks to the location of the Longxian site in the funnel-shaped entrance of a trough (Fig. 7).

\subsection{Possible other types of reworking}

As explained above, the occasional gravity flows running down the basin slope must by definition have crossed the continuously flowing contour current. Because the energy level of turbidity currents is, as a rule, significantly higher than that of contour currents, it is to be expected that turbidity currents meeting contour currents can erode the deposits left by the latter. There is evidence, indeed, in the form of the types of grains in some turbidites.

Some turbidites elsewhere in the Pingliang Formation appear to be moderately to moderately well sorted, which is not common for turbidites, but much more for contourites. Also considering the rounding of the grains in some turbidites, it cannot be excluded that contour currents contributed material, indicating that the turbidity currents eroded contourites. There is, however, no unambiguous proof.

There are other traces of interaction, however, that are not only better understandable, but that also have been proven. These concern the (partial) erosion of contour currents by debris flows. Yang et al. (2019) show a nice example of such erosion (Fig. 4C).

\section{Implications for hydrocarbon occurrences}

The Pingliang Formation is built partly by large submarine fans with abundant sand units that form 
potential hydrocarbon reservoirs. The contour current was able, particularly where it had a relatively high erosional capability, to winnow, sort, and rework fine-grained turbidites, thus improving the maturity of the sandstones, which is expressed by a higher porosity and permeability.

One of these submarine fans is situated in the study area; two more are also developed along the western margin of the basin, thus forming a series from north to south. They consist mainly of medium- to fine-grained sandstones with grain sizes in the range of 2.1-5 $\varphi$, resulting in a sorting coefficient of 0.55 . The quartz grains, which constitute on average some $75 \%$, are subangular to subrounded. Due to advanced diagenesis, the porosity ranges from $2 \%$ to $4 \%$, and the permeability ranges from 0.1 millidarcy to 0.5 millidarcy.

The reworked turbidites at Longxian form a tight reservoir. There are, however, potentially better reservoirs in the form of three large submarine fans that are present along the western margin of the Ordos Basin. One of them is located nearby Longxian. In one of the other fans the hydrocarbon potential was investigated through exploration wells. In the Lushen-1 well, the thickness of the sand is $286 \mathrm{~m}$, the quartz content is $36-70 \%$; the grains are subrounded, and the degree of sorting is intermediate. This supports our conclusions regarding the reworking of turbidites by a contourite at Longxian. In the Kushen-1 well, the thickness of the sand is $112 \mathrm{~m}$ (Xi et al., 2006).

The turbidites form a potential reservoir. If such a reservoir would be affected by partial erosion, this might result in loss of sealing capacity. For this reason, the finding that a contourite affected the finegrained upper parts of turbidites, and that possibly turbidites eroded locally the contourites, is important for the exploration for hydrocarbons.

\section{Conclusions}

The interaction between turbidity currents and contour currents in the study area was examined on the basis of lithology, sedimentary structures, granulometry and paleocurrent analysis.

The presence of turbidites in the study area is obvious. Part of them are sandy, grading to silty/ clayey in their top part. The sandstone turbidites show occasionally flute and groove casts at their base, and are characterized by complete or incomplete Bouma divisions, with grading, horizontal lamination, small-scale cross-bedding and parallel lamination, sometimes followed by a silty top part without visible structures. The grains are angular to subangular. Both the sole marks and the current ripples show downslope transport.

Contourites are absent in the Longxian site, but they occur in the Fuping and Pingliang sites. The responsible current ran from East to West and must have passed the Longxian site; the absence of contourites at this site must be explained by reworking by the higher-energy turbidity currents and other gravity flows. The contourites at Fuping and Longxian consist of calcarenites and micrites and show cross-lamination that indicates alongslope transport, more or less perpendicular to the transport direction of the gravity flows. The contourites contain mostly rounded grains.

Because the contour current and the gravity flows ran in mutually more or less perpendicular directions, the permanent contour current must occasionally have been hit by the periodic gravity flows. Because the gravity flows (including the turbidity currents) involved a much larger mass (and had also a much higher velocity and consequently a much higher kinetic energy) than the contour current at the place where they crossed, they could in most cases erode the still unconsolidated and water-saturated contourite deposits and embedded them in their own mass. This explains the absence of clearly developed contourites at Longxian.

Occasionally, however, reworking of the finegrained top part of turbidites by the contour current took place. This can be deduced not only from the different paleocurrent directions that can be found within a single layer (the current ripples in the lower part of the turbidite indicate the downslope direction of the flow, whereas the current ripples in the reworked fine-grained top part indicate the alongslope transport by the contour current), but also from the various grain-size characteristics of the deposits. The grains in the reworked part of the turbidite are on average more rounded than in other turbidites (because rounded grains from the contourite are included), and the sorting is for the same reason better than on average in other turbidites.

Although contourites are recognized in ever more deep basins, and because gravity flows are common features in basins with slopes where a high sedimentation rate occurs, there must have been countless places in the geological past where contour currents crossed gravity flows. Yet, descriptions of ancient sediments with features indicating such a situation are extremely rare, and not very precise. This is understandable for two reasons, even if it is taken into account that the sedimentary record has preserved only a fraction of the sediments that once were deposited: (1) in many cases, the traces left by the interaction of both types of cur- 
rents will have been erased by continued activity of the contour current and/or the gravity flow, and (2) the chance of finding an exposure with such a feature is extremely small if it is realized how large deep-marine (or deep-lacustrine) basins are in comparison to exposed rocks. The example presented here consequently represents a phenomenon that has, as far as the authors are aware of, not been described in any detail earlier from ancient deposits.

\section{Acknowledgements}

The authors are grateful to Wei Huang, Zhuruizhi Liu, Jin Zhang, Can Zhang, Jixin Wang and Jin Huang for collecting data in the field. This research was supported by the National Natural Science Foundation of China (grants No. 41472096 and 41502101), the Group Innovation Fund of HuBei Province (grant No. 2015CFA024), the Yangtze Youth Fund of Yangtze University (grant No. 2015cqn26) and the Youth Talent Project of the Science Research Program of the Education Department of Hubei Province of China (grant No. Q20171308) and the National Science and Technology Major Project of the Ministry of Science and Technology of China (grant No. 2017ZX05032002-003).

\section{References}

Bouma, A.H., 1962. Sedimentology of some flysch deposits. A graphic approach to facies interpretation. Elsevier, Amsterdam, $168 \mathrm{pp}$.

Duan, T.Z., Gao, Z.Z., Zeng, Y.F. \& Stow, D.A.V., 1993. A fossil carbonate contourite drift on the Lower Ordovician palaeocontinental margin of the middle Yangtze Terrane, Jiuxi, northern Hunan, southern China. Sedimentary Geology 82, 271-284.

Fang, G.Q. \& Mao, M.J. , 2007. Trace fossils and sedimentary environments of Upper Ordovician of Fuping in Shaanxi, China. Journal of Tongji University (Natural Science) 35, 1118-1121 (in Chinese with English abstract).

Gao, Z.Z., Kenneth A.E., He, Y.B. \& Luo, S.S., 1998. Deep-water tractive current deposits - The study of internal-tide, internal-wave, and contour current deposits. Science Press, Beijing and New York, 77-113.

Gao, Z.Z., Luo, S.S., He, Y.B. Zhang, J.S. \& Tang, Z.J., 1995. The Middle Ordovician contourite on the west margin of Ordos. Acta Sedimentologica Sinica 13, 16-26 (in Chinese with English abstract).

Gong, C.L., Wang, Y.M., Rebesco, M., Salon, S. \& Steel, R.J., 2018. How do turbidity flows interact with contour currents in unidirectionally migrating deep-water channels? Geology 46, 551-554.
Gong, C.L., Wang, Y.M., Zhu, W.L., Li, W.G. \& Xu, Q., 2013. Upper Miocene to Quaternary unidirectionally migrating deep-water channels in the Pearl River Mouth Basin, northern South China Sea. AAPG Bulletin 97, 285-308.

Gong, C.L., Wang, Y.M., Xu, S., Pickering, K.T., Peng, X.C., Li, W.G. \& Qiu, Y., 2015. The northeastern South China Sea margin created by the combined action of down-slope and along-slope processes: Processes, products and implications for exploration and paleoceanography. Marine and Petroleum Geology 64, 233 249.

Gong, C.L., Wang, Y.M., Zheng, R.C., Hernández-Molina, F.J., Li, Y., Stow, D.A.V., Xu, Q. \& Brackenridge, R.E., 2016. Middle Miocene reworked turbidites in the Baiyun Sag of the Pearl River Mouth Basin, northern South China Sea margin: Processes, genesis, and implications. Journal of Asian Earth Sciences 128, 16-129.

Gonthier, E., Faugères, J.-C., Viana, A., Figueiredo, A. \& Anschutz, P., 2003. Upper Quaternary deposits on the Sao Tomé deep-sea channel levee system (South Brazilian Basin): major turbidite versus contourite processes. Marine Geology 199, 159-180.

Guo, Y.R., Zhao, Z.Y., Xu, W.L., Shi, X.Y., Gao, J.R., Bao, H.P., Liu, J.B., Zhang Y.L. \& Zhang Y.Q., 2014. Sequence stratigraphy of the Ordovician system in the Ordos Basin. Acta Sedimentologica Sinica 32, 44-60 (in Chinese with English abstract).

He, Y.B., Gao, Z.Z., Luo, S.S., Peng, D.T., Wang, H.W. \& Luo, J.X., 2007. Discovery of internal-tide deposits from the Third Member of Pingliang Formation in Longxian area, Shananxi province. Journal of Oil and Gas Technology 29(4), 28-33 (in Chinese with English abstract).

Heezen, B.C., Hollister, C.D. \& Ruddiman, W.F., 1966. Shaping of the continental rise by deep geostrophic contour currents. Science 152, 502-506.

Hernández-Molina, F.J. \& Stow, D.A.V., 2008. Continental slope contourites. [In:] Rebesco, M. \& Camerlenghi, A. (Eds): Contourites. Developments in Sedimentology (Elsevier, Amsterdam) 60, 379-408.

Hernández-Molina, F.J., Paterlini, M., Violante, R., Marshall, P., Isasi, M., Somoza, L. \& Rebesco, M., 2009. Contourite depositional system on the Argentine Slope: An exceptional record of the influence of Antarctic water masses. Geology 37, 507-510.

Hernández-Molina, F.J., Sierro, F.J., Llave, E., Roque, C., Stow, D.A.V., Williams, T., Lofi, J., Schee, M.V.D., Arnáiz, A., Ledesma, S., Rosales, C. \& RodríguezTovar, F.J., 2015. Evolution of the Gulf of Cadiz margin and southwest Portugal contourite depositional system: Tectonic, sedimentary and paleoceanographic implications from IODP expedition 339. Marine Geology 377, 7-39.

Kähler, G. \& Stow, D.A.V., 1998. Turbidites and contourites of the Palaeogene Lefkara Formation, southern Cyprus. Sedimentary Geology 115, 215-231.

Kenyon, N.H., Akhmetzhanov, A.M. \& Twichell, D.C., 2002. Sand wave fields beneath the Loop Current, Gulf of Mexico: Reworking of fan sands. Marine Geology 192, 297-307. 
Kuvaas, B., Kristoffersen, Y., Guseva, J., Leitchenkov, G., Gandjukhin, V., Løvås, O., Sand, M. \& Brekke, H., 2005. Interplay of turbidite and contourite deposition along the Cosmonaut Sea/Enderby Land margin, East Antarctica. Marine Geology 217, 143-159.

Li, H., He, Y.B., Huang, W., Liu, Z.R. Z. \& Zhang, J., 2016. Contourites of the Ordovician Pingliang Formation in southern margin of Ordos Basin. Journal of Palaeogeography 18, 631-642 (in Chinese with English abstract).

Li, H., He, Y.B., Liu, Z.R., Huang, Z., Zhang, J. \& Zhang, C., 2017. Characteristic of gravity flow deposit in Pingliang Formation of Ordovician the southwest margin of the Ordos Basin. China Science Paper 12, 1774-1779 (in Chinese with English abstract).

Li, H., Wang, Y.M., Xu, Q., Zhuo, H.T., Wu, J.P., Tang, W., Li, D.\& Xu, Y.X., 2014. Interactions between downslope and along-slope processes on the northern slope of South China Sea: Products, processes, and depositional model. Acta Geologica Sinica 88, 1120-1129 (in Chinese with English abstract).

Li, H., Wang, Y.M., Zhu, W.L., Xu, Q., He, Y.B., Tang, W., Zhuo, H.T., Wang, D., Wu, J.P. \& Li, D. 2013. Seismic characteristics and processes of the Plio-Quaternary unidirectionally migrating channels and contourites in the northern slope of the South China Sea. Marine and Petroleum Geology 43, 370-380.

Li, W.H., Mei, Z.C., Chen, W.T., Lu, H.Y., Zhang, G.Y. \& Liu, H.Q., 1991. The paleoslope and paleoflow direction of deposits in the Middle-Late Ordovician in Fuping county, Shaanxi province. Journal of Xi'an College of Geology 13, 36-41 (in Chinese with English abstract).

Liu, C., Qin, S., Su, W.B. \& Fu, L.P., 2013. Microfacies response to the drowning process of the carbonate platform: A case study on the Ordovician succession at the Taoqupo Section, Tongchuan city, Shaanxi province, north China Block. Geological Survey and Research 36, 23-38 (in Chinese with English abstract).

Marchès, E., Mulder, T., Gonthier, E., Cremer, M., Hanquiez, V., Garlan, T. \& Lecroart, P., 2010. Perched lobe formation in the Gulf of Cadiz: Interactions between gravity processes and contour currents (Algarve Margin, southern Portugal). Sedimentary Geology 229, 81-90.

Massé, L., Faugères, J.-C. \& Hrovatin, V., 1998. The interplay between turbidity and contour current processes on the Columbia Channel fan drift, Southern Brazil Basin. Sedimentary Geology 115, 111-132.

Michels, K., Rogenhagen, J. \& Kuhn, G., 2001. Recognition of contour-current influence in mixed contourite-turbidite sequences of the western Weddell Sea, Antarctica. Marine Geophysical Researches 22, 465-485.

Middleton, G.V. \& Hampton, M.A., 1973. Sediment gravity flows: Mechanics of flow and deposition. [In:] Middleton, G.V. \& Bouma, A.H. (Eds): Turbidites and deep water sediments. SEPM Pacific Section Short Course, $1-38$.

Mulder, T., Faugères, J.-C. \& Gonthier, E., 2008. Mixed turbidite-contourite systems. [In:] Rebesco, M. \& Camerlenghi, A. (Eds): Contourites. Developments in Sedimentology (Elsevier, Amsterdam) 60, 435-456.
Mulder, T., Migeon, S., Savoye, B. \& Faugères, J. C., 2001. Inversely graded turbidite sequences in the deep Mediterranean: a record of deposits from flood-generated turbidity currents? Geo-Marine Letters 21, 86-93.

Mulder, T., Lecroart, P., Hanquiez, V., Marches, E., Gonthier, E., Guedes, J.-C., Thiébot, E., Jaaidi, B., Kenyon, N., Voisset, M., Perez, C., Sayago, M., Fuchey, Y. \& Bujan, S., 2006. The western part of the Gulf of Cadiz: contour currents and turbidity currents interactions. Geo-Marine Letters 26, 31-41.

Mutti, E., Bernoulli, D., Ricci, F. \& Tinterri, R., 2009. Turbidites and turbidity currents from Alpin 'flysch' to the exploration of continental margins. Sedimentology 56, 267-318.

Qu, H.J., Mei, Z.C., Li, W.H., Guan, L.Q., Feng, Y.W. \& Fan, Y.H., 2010. The characteristics of Middle Ordovician contour current deposits and geological implication in Fuping region, Shaanxi Province, China. Geological Bulletin of China 29, 1304-1309 (in Chinese with English abstract).

Rasmussen, S., Lykke-Andersen, H., Kuijpers, A. \& Troelstra, S.R., 2003. Post-Miocene sedimentation at the continental rise of Southeast Greenland: the interplay between turbidity and contour currents. Marine Geology 196, 37-52.

Rebesco, M, Camerlenghi, A. \& Van Loon, A.J., 2008. Contourite research: a field in full development. [In:] Rebesco, M., Camerlenghi, A. (Eds): Contourites. Developments in Sedimentology (Elsevier, Amsterdam) 60, 3-8.

Rebesco, M., Hernández-Molina, F. J., Rooij, D.V. \& Wåhlin, A., 2014. Contourites and associated sediments controlled by deep-water circulation processes: Stateof-the-art and future considerations. Marine Geology 352, 111-154.

Rooij, D.V., Iglesias, J., Hernández-Molina, F.J., Ercilla, F., Gomez-Ballesteros, M., Casas, D., Llave, E., Hauwere, A.D., Garcia-Gil, S., Acosta, J. \& Henriet, J.-P., 2010. The Le Danois contourite depositional system: Interactions between the Mediterranean outflow water and the upper Cantabrian slope. Marine Geology 274, 1-20.

Salles, T., Marchès, E., Griffiths, C., Hanquiez, V. \& Mulder, T., 2010. Simulation of the interactions between gravity processes and contour currents on the Algarve Margin (South Portugal), using the stratigraphic forward model. Sedimentary Geology 229, 95-109.

Shanmugam, G., Spalding, T.D. \& Rofheart, D.H., 1993a. Process sedimentology and reservoir quality of deep marine bottom-current reworked sands (sandy contourites): An example from the Gulf of Mexico. AAPG Bulletin 77, 1241-1259.

Shanmugam, G., Spalding, T.D. \& Rofheart, D.H., 1993b. Traction structures in deep-marine, bottom-current-reworded sands in the Pliocene and Pleistocene, Gulf of Mexico. Geology 21, 929-932.

Song, S.G., Niu, Y.L., Su, L. \& Xia, X.H., 2013. Tectonics of the North Qilian Orogen, NW China. Gondwana Research 23, 1378-1401. 
Stanley, D.J., 1993. Model for turbidite-to-contourite continuum and multiple process transport in deep marine settings: examples in the rock record. Sedimentary Geology 82, 241-255.

Stow, D.A.V. \& Faugères, J.-C., 2008. Contourite facies and the facies model. [In:] Rebesco M., Camerlenghi, A. (Eds): Contourites. Developments in Sedimentology (Elsevier, Amsterdam) 60, 223-256.

Stow, D.A.V. \& Lovell, J.P.B., 1979. Contourites: Their recognition in modern and ancient sediments. Earth-Science Reviews 14, 251-291.

Stow, D.A.V., Gisell, K. \& Mike, R., 2002. Fossil contourites: type example from an Oligocene palaeoslope system, Cyprus. [In:] Stow, D.A.V., Pudsey, C.J., Howe, J.A., Faugères, J.-C. \& Viana, A.R. (Eds): Deep-water contourite systems: modern drifts and ancient series, seismic and sedimentary characteristics. Geological Society (London) Memoir, 443-455.

Stow, D.A.V., Faugères, J.-C., Viana, A. \& Gonthier, E., 1998. Fossil contourites: a critical review. Sedimentary Geology 115, 3-31.

Stow, D.A.V., Hernández-Molina, F.J., Llave, E., Sayago-Gil, M., Río, V.D. \& Branson, A., 2009. Bedform-velocity matrix: The estimation of bottom current velocity from bedform observation. Geology 37, 327-330.

Viana, A.R., 2008. Economic relevance of contourites. [In:] Rebesco, M., Camerlenghi, A, (Eds.): Contourites. Developments in Sedimentology (Elsevier, Amsterdam) 60, 493-510.

Viana, A., de Almeida, W. \& de Almeida, C.W., 2002. Upper slope sands: late Quaternary shallow-water sandy contourites of the Campos basin, SW Atlantic margin. Geological Society, London, Memoir 22, 261-270.

Wang, Z.T., Zhou, H.R., Wang, X.L., Zhang, Y.S., Jing, X.C. \& Xing, E.Y., 2015. Ordovician geological events group in the west and south Ordos Basin. Acta Geologica Sinica 89, 1990-2004 (in Chinese with English abstract).
Wetzel, A. \& Stow, D.A.V., 2008. Bioturbation and biogenic sedimentary structure in contourites. [In:] Rebesco, M., Camerlenghi, A. (Eds): Contourites. Developments in Sedimentology (Elsevier, Amsterdam) 60, 183-202.

Wu, S.H. \& Feng, Z.Z., 1994. Sedimentology of gravity flow deposits of Middle Ordovician Pingliang Formation in west and south margins of Ordos. Oil $\mathcal{E}$ Gas Geology 15, 226-234 (in Chinese with English abstract).

Xi, S.L., Li, Z.H., Wang, X. \& Zheng, C.B., 2006. Distribution and exploration potential of Ordovician reservoir in Ordos Basin. Oil \& Gas Geology 27, 405-412 (in Chinese with English abstract).

Yang, R., Fan, A., Han, Z. \& Van Loon, A.J., 2017. Lithofacies and origin of the Late Triassic lacustrine muddy gravity-flow deposits and their soft-sediment deformation structures in the Ordos Basin, central China. Marine and Petroleum Geology 85, 194-219.

Yang, R., Van Loon, A.J., Jin, X., Jin, Z., Han, Z., Fan, A. \& Liu, Q., 2019. From divergent to convergent plates: resulting facies shifts along the southern and western margins of the Sino-Korean Plate during the Ordovician. Journal of Geodynamics https:/ / doi.org/10.1016 / j.jog.2018.02.001.

Yuan, X.Q., Su, D.C., He, J., Sun, A.P., Lv, H.B., Li, H.B. \& Qiao, X.F., 2014. The slump structures in the Middle Ordovician on the southern margin of Ordos Basin and their seismic origin. Geological Review 60, 529-540 (in Chinese with English abstract).

Zhou, S.C., Feng, Q., Zhao, W., Wang, Q.Y., Liu, Z., Jiang, W.J. \& Li, Y.L., 2011. Sedimentary environments of the Middle Ordovician Pingliang Formation in the Qishan section, southern Ordos Basin. Sedimentary Geology and Tethyan Geology 31(4), 28-33 (in Chinese with English abstract).

Manuscript received: 25 August 2018 Revision accepted: 15 January 2019 